Short Report

\title{
Estimation of Cell Damage in Monolayer Culture Using ${ }^{14} \mathrm{C}$-Leucine Incorporation
}

\author{
Tetsuro Kato, Kryoshi Ishikawa and Ryosuke Nemoto \\ Department of Urology, Akita University School of Medicine, \\ Akita
}

Kato, T., Ishikawa, $\mathrm{K}$. and Nenoro R. Estimation of Cell Damage in Monolayer Culture Using ${ }^{14}$ C-Leucine Incorporation. Tohoku J. exp. Med., 1977, 121 (4), 403-404 - A comparison was made of ${ }^{14} \mathrm{C}$-lencine incorporation and cell viability of T24 human bladder carcinoma cells after treatment with Thio-Tepa, a potent alkylating agent. It was found that Thio-Tepa produced concentrationdependent damage in these cells and also that ${ }^{14} \mathrm{C}$-lencine incorporation correlated well with cell viability. ${ }^{14} \mathrm{C}$-leucine incorporation can be used as a reliable and rapid screening test for the assessment of the relative potencies of anticancer drugs. $-{ }^{14} \mathrm{C}$-leucine incorporation; cell viability; $\mathrm{T} 24$ cells; Thio-Tepa

Various cytotoxic tests have been used for in vitro screening of anti-cancer drugs as well as a variety of therapeutic maneuvers. Among them cell viability measured by dye exclusion technique and colony forming efficiency are most commonly used for the assessment of cytotoxicity. Although these methods have considerable advantages, they are not easily applicable to monolayer cultures because of their difficulties in manipulation requiring large numbers and sizes of samples. Isotopic technique may overcome such difficulties. The purpose of this study is to determine if ${ }^{14} \mathrm{C}$-leucine incorporation into monolayer culture can be used as a measure of cell viability.

\section{Materials and Methods}

T24 cells established from human bladder carcinoma (Bubenik et al. 1973; Kato 1976) were cultured in glass test tubes containing Eagle's MEM medium supplemented with $10 \%$ fetal calf serum. The log-phase cells on day 3 of culture were exposed to Thio-Tepa (Triethylen Thiophosphoramide, a potent alkylating agent for bladder carcinoma) at concentrations of $10,50,100$ and $200 \mu \mathrm{g} / \mathrm{ml}$ for $2 \mathrm{hr}$. The cells were labeled with $0.5 \mu \mathrm{Ci} / \mathrm{ml}$ of ${ }^{1 *} \mathrm{C}$-leucine (specific activity $250 \mathrm{mCi} / \mathrm{mM}$, New England Nuclear ( o.) for $24 \mathrm{hr}$ in sequence of time after the treatment. The cells were then washed with cold saline, fixed with acetic ethanol, extracted with two 15 min washes of ice cold $5 \%$ trichloroacetic acid and rinsed with distilled water. Following air dry, the cells were dissolved in $2 \mathrm{ml}$ of $0.5 \mathrm{~N} \mathrm{NaOH}$. The samples were mixed with PCS scintillator (Amersham/Searle Co.) and the radioactivity was measured by a scintillation counter (Nuclear Chicago Co.). Viable cell numbers were counted by a trypan blue exclusion method. Each study was done in triplicate and followed by 10 days.

\section{Results AND Discussion}

Fig. 1 illustrates changes in the mean value of ${ }^{14} \mathrm{C}$-leucine incorporation and viable

Received for publication, February 9, 1977. 


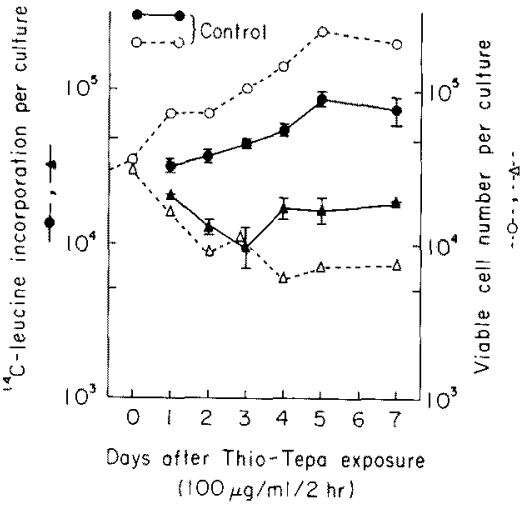

Fig. 1

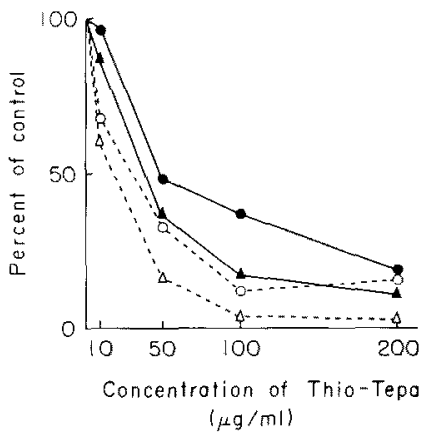

Fig. 2

Fig. 1. ${ }^{14} \mathrm{C}$-leucine incorporation (cpm, 1 mean \pm s.D.) and viable cell number of $\mathrm{T} 24$ cells after Thio-Tepa exposure.

Fig. 2. Dose response curves expressed as percentage of the control values on days 2 and 5 after Thio-Tepa exposure. The curves were represented by ${ }^{14} \mathrm{C}$-leucine incorporation (-- day 2, - - day 5) and cell viability (--o--day 2, ..... day 5).

cell number as a function of time after exposure to $100 \mu \mathrm{g} / \mathrm{ml}$ of Thio-Tepa. The radioactivity correlates well with the cell viability of both the treated and untreated cells. The radioactivity per unit cell number in the treated cells, however, is usually higher than that of the control. This could be explained on the basis of either increased metabolic activity or reutilization of the isotope released from the dead cells after the drug treatment, or in combination.

Fig. 2 shows the dose response curves expressed as the percentage of the control values. The radioactivity correlates well with the cell viability. Moreover, the dose response curves of days 2 and 5 after the treatment are similar. Previous investigators (Sawada et al. 1972; Schechter et al. 1976) have suggested that protein synthesis is a reliable measure of cytotoxicity in immunological studies. The results of the present study indicate that ${ }^{14} \mathrm{C}$-leucine incorporation can be used as a rapid and sensitive screening test for the assessment of the relative potencies of anti-cancer drugs.

\section{References}

1) Bubenik, J., Baresova, M., Viklicky, V., Jakoubkova, J., Saninerova, H. \& Donner, J. (1973) Established cell line of urinary bladder carcinoma (T24) containing tumorspecific antigen. Brit. J. Cancer, 11, 765-773.

2) Kato, T. (1976) Cell kinetics of the bladder carcinoma. I. Cell cycle analysis of the cultured human bladder carcinoma cells. Jap. J. Urol., 67, 491-496.

3) Sawada, J., Osawa, T. \& Shiori-Nakano, K. (1972) Guinea pig lymphotoxin and comparison of various assay methods for cytotoxieity. Transplantation, 14, 771-776.

4) Schechter, B., Treves, A.J. \& Feldman, M. (1976) Specific cytotoxicity in vitro of lymphocytes sensitized in culture against tumor cells. $J$. Nat. Cancer Inst., 56, 975-979. 